\title{
Phytohormones content and random amplified polymorphic DNA (RAPD) marker assessment of some Egyptian citrus cultivars
}

\author{
Hala F. Ahmed \\ Department of Botany, Faculty of Science, Ain Shams University, Cairo, Egypt. E-mail: dr.hala.f.ahmed@gmail.com.
}

Accepted 26 September, 2012

\begin{abstract}
In Egypt, Citrus represents one of the main fruit tree crops for both local and export potentials. In this study, leaf and vegetative bud samples were studied for cultivars of sour orange (seedless, sweet seeded, Brazilian and Spanish), common sweet orange (Florida, Fsido, Shamoty, and Valencia) and navel orange B29 from four different areas in Egypt (El-Qalubaiya governorate, Wadi El-Mollak; Ismailia governorate, El-Salheia; Sharqaia governorate, and El-Minya; South Egypt). Cluster analysis generated by random amplified polymorphic DNA (RAPD) molecular marker showed close similarities of the four sour orange accessions, used as rootstocks, where they were grouped in one cluster. The four cultivars of sweet common orange and sweet navel orange was linked together in a separate cluster. Navel orange cultivated at El-Minya and El-Salheia showed drop in yield due to substantial flower and young fruit abscission, whereas trees of the same cultivar did not suffer from abscission and yielded enhanced crop. Comparison of the four previously mentioned localities speculated that the navel orange accessions at El-Minya and El-Salheia are subjected to drought stress. This could be further verified by the substantially enhanced levels of abscisic acid in the plants showing abscission, as compared to those exhibiting normal flowering and enhanced fruiting at El-Qalubaiya and Wadi ElMollak.
\end{abstract}

Key words: Abscisic acid, abscission, Citrus, cluster analysis, deoxyribonucleic acid (DNA) random amplified polymorphic DNAs (RAPDs), drought, rootstock, scions.

\section{INTRODUCTION}

Citrus species are among the most widely grown fruit crops in the world and have a large market worldwide. In Egypt, some Citrus species have been cultivated traditionally since ancient times. Egypt is considered as the 9th largest Citrus producer in the world, with an annual production approximately estimated as 3, 200, 000 tons, which represents about $2.92 \%$ of the total world production (FAO, 2006).

The genus Citrus belongs to family Rutaceae, subfamily Aurantoideae (Tanaka, 1977). This genus has many species; the main cultivated species are sweet orange (Citrus sinensis (L.) Osbeck), mandarin (C. reticulate Blanco), grape fruits (C. paradisi Macf.), lemons (C. limon (L.) Burm., f. (lemon), and sour orange (Citrus aurantium L.). Ollitrault et al. (2010) stated that Citus is a diploid genus whose cultivated forms play a major role in the human diet with more than $122 \mathrm{MT}$ of the world annual production.

In Egypt, Citrus cultivation has doubled in area over the past 25 years. The fruit bearing area reached more than 140, 000 ha in 2004 (Hofer, 2007). During the last decade, the private sector invested into establishment more than 10000 ha new plantations in the desert outside the Nile valley. More than one fourth of the total Citrus production, now, comes from the "new lands" in the desert. Approximately, half of the total acreage in the country is cultivated by large-scale farms, whereas the other half is cultivated by small-scale growers.

The national average Citrus yield in Egypt is very low compared to world levels (FAO, 2006). The main reasons for the low productivity are inappropriate cultivation practices, old trees, lack of regular pruning, off-type cultivars, and poor irrigation practices, as well as grafttransmissible diseases (Hofer, 2007). 
In Egypt, Citrus productivity is determined by diverse environmental stimuli. In this context, navel sweet orange (Citrus sinesis cv. B29) produces a high yield at ElQalubaiya governorate and Wadi El-Mollak (Ismailia governorate). However, at El-Salheia (Sharqaia governorate) and El-Minya (South Egypt), the crop yield is very low, where the trees are subjected to severe flower and young fruit abscission. Main variation among the three aforementioned mentioned areas could be attributed to the moisture content which is markedly lower at the sites showing abscission (weather forecast, 2011).

The use of molecular markers has been followed as a valuable and precise strategy to physiological and molecular studies on Citrus. Among them, random amplified polymorphic DNA (RAPDs) has been employed most widely. Thus, RAPDs have been used for cultivar identifycation, genetic mapping, genetic diversity assessment and other breeding programs (Dehesdtani et al., 2007). In the genus Citrus, information dealing with the generation of genomic tools and resources was reviewed by Talon and Gmitter (2008) and by Tadeo et al. (2008) on the progress in molecular biology and genetics of development.

Navel oranges (characterized by the growth of a second fruit at the apex, which protrudes slightly and resembles a human navel) are economically important since they are very popular because of their use as a tasty eating orange, their widespread distribution, and their long growing season. Navel oranges (resulted from a single mutation) are characterized by a rather thicker skin which is easier to peel than common orange (Kimball, 1999). Because the mutation left the fruit seedless, and therefore sterile, the only mean of cultivation of new variety is to graft cuttings onto other varieties of Citrus. Rootstock influences not only the rate of growth, disease resistance and productivity of the cultivar but also the physical and chemical attributes of the crop (Chang-pin et al., 2010). Because all navel oranges are clones of one another, they are highly susceptible to various environmental factors (Wutscher and Bowman, 1999). Therefore, environmental changes in climatic factors, nature of soil, etc. create a demand for new Citrus rootstocks and assessment of some genetic and physiological traits of the present Citrus trees, where some of which have ambiguous origin and dates of introduction (Dehesdtani et al., 2007; Snoussi et al., 2012). Moreover, adequate genetic diversity is necessary in breeding programs for the development of high yielding varieties (Golein et al., 2012). Thus, understanding phylogenetic relationships and genetic diversity in the Citrus resources in Egypt is important for optimizing their use; which will help for further physiological and agronomical evaluations and breeding programs.

The elements and mechanisms whereby environmental and cellular stimuli affect physiological criteria as flower and fruitlet abscission in Citrus are triggered by hormonal signals (Iglesias et al., 2007). In this respect, gibberellins
(GAs) are known to inhibit flower production in Citrus species, which is in contrast to its flowering promoting effect in annual plants (Guardiola et al., 1982; Lliso et al., 2004). On the other hand, auxins have been reported to act as stimulators of growth and also as abscission agents, perhaps through promoting ethylene synthesis (Iglesias et al., 2007). Enhanced abscisic acid levels coincided the abscission waves in ovaries of Citrus at petal fall and during the transition from cell division to cell enlargement in fruits (Goren, 1993). This hormone is also high over periods of low humidity, dehydration and salt or drought conditions which are known to induce abscission (Mehouachi et al., 2005; Agusti et al., 2007; Tang et al., 2012). Taken together, it is concluded that GA deficiency is associated with ABA rise and ethylene release, and eventually ovary abscission (Gomez-Cadenas et al., 1996).

Thus, the present work intended to investigate: (a) interrelations of 12 accessions of Citrus that are used in Egypt as root stocks and scions in the breeding programs, on the bases of RAPD and (b) measuring phytohormone levels in the plants grown at different localities that underlie variable yield potentials.

\section{MATERIALS AND METHODS}

The current investigation was carried out on 12 accessions of Citrus cultivars in Egypt. The plant materials used in the present investigation was obtained from the Agriculture Research Centre, Giza, Egypt. Fresh young leaves (first and second leaves from branch tops) of Citrus were collected in ice box, transferred to laboratory, and then stored at $-20^{\circ} \mathrm{C}$ until use for DNA extraction and randomly amplified polymorphic DNA polymerase chain reaction (RAPD-PCR). Terminal buds and young leaves at branch tops were similarly collected in $80 \%$ redistilled ethanol [High-performance liquid chromatography (HPLC) grade] and kept in a deep freeze $\left(-20^{\circ} \mathrm{C}\right)$ till use. The 12 accessions under study presented four cultivars of sour orange (seedless, seeded, Brazilian and Spanish), four cultivars of sweet common oranges (Florida, Fsido, Shamoty, and Valencia). In addition, four accessions of navel orange B29 were similarly collected from farms under supervision of the Agriculture Research Centre at El-Qalubaiya governorate, Wadi El-Mollak (Ismailia governorate), El-Salheia (Sharqaia governorate) and El-Minya (South Egypt). All samples were collected in middle June.

All chemicals and hormone authentics were perched from Sigma Aldrich Company. The DNA primers were obtained from the Operon Technology Inc., Alameda, CA, USA.

\section{Deoxyribonucleic acid (DNA) extraction}

Isolation of total genomic DNA for random amplified polymorphic DNA (RAPD) was carried out according to Dellaporta et al. (1983), with slight modification as follows: leaf pieces were washed with tap water, rinsed twice in sterile distilled water and ground with liquid nitrogen in a sterile mortar and pestle. The powder obtained (about $200 \mathrm{mg}$ ) was transferred to a micro centrifuge $1.5 \mathrm{ml}$ tube and resuspended in $600 \mathrm{ml}$ extraction buffer [120 mM Tris, $\mathrm{pH} 8.2,800$ $\mathrm{mM} \mathrm{NaCl}, 50 \mathrm{mM}$ EDTA, $1 \%$ sodium dodecyl sulphate (SDS), $0.2 \%$ $\beta$-Mercaptoethanol]. Samples were incubated for $45 \mathrm{~min}$ at $65^{\circ} \mathrm{C}$ water bath and then $300 \mathrm{ml} \mathrm{M} \mathrm{KCl}$ was added. The tubes were 
Table 1. Sequences of primer.

\begin{tabular}{cc}
\hline Primer & Sequence 5' $-\mathbf{3}^{\prime}$ \\
\hline OPA-03 & AGTCAGCCAC \\
OPA-07 & GAAACGGGTG \\
OPA-14 & TCTGTGCTGG \\
OPA-19 & CAAACGTCGG \\
OPA-20 & GTTGCGATCC \\
OPA-04 & GGACTGGAGGT \\
OPA-06 & GAACGGACTC \\
OPA-05 & CTGAGACGGA \\
OPA-06 & GTGCCTAACC \\
OPA-07 & GAACCTGCGG \\
\hline
\end{tabular}

carefully inverted several times, left for $10 \mathrm{~min}$ at room temperature and centrifuged at $10000 \mathrm{~g}$ for $10 \mathrm{~min}$. The supernatant was transferred to a new micro centrifuge tube, one volume chloroform/ isoamyl alcohol (24:1) was added and after several inversion, they were centrifuged at $12000 \mathrm{~g}$ for $10 \mathrm{~min}$. The supernatant was transferred to a new micro centrifuge tube and was precipitated with an equal volume of 2-isopropanol for $15 \mathrm{~min}$ at $4{ }^{\circ} \mathrm{C}$ and centrifuged again at $12000 \mathrm{~g}$ for $8 \mathrm{~min}$. The crude DNA pellet was washed with ice-cold $80 \%$ ethanol, dried for $20 \mathrm{~min}$ at room temperature and resuspended in $70 \mu \mathrm{l}$ Tris EDTA (TE) buffer. DNA was quantified by agarose electrophoresis gels after ethidium bromide staining. The bands were detected on UV-trans illuminator and photographed by Polaroid camera.

Randomly amplified polymorphic DNA polymerase chain reaction (RAPD-PCR)

Reactions were conducted using the DNA of the 12 genotypes under investigation and 10 primers, which generated reproducible quite polymorphic bands, were used further for data analysis. The sequences of these primers are shown in Table 1.

The reaction conditions and the mixtures used were according to Ahmed et al. (2005). Amplification was carried out using a programmed PCR for 42 cycles as follows: $94^{\circ} \mathrm{C} / 4 \mathrm{~min}$ (one cycle); 94,37 , and $72^{\circ} \mathrm{C} / 2 \mathrm{~min}\left(40\right.$ cycles); $72^{\circ} \mathrm{C} / 10 \mathrm{~min}(1 \mathrm{cycle}), 4^{\circ} \mathrm{C} /$ infinitive.

\section{Cluster analysis}

Each DNA band was scored as present (1) or absent (0) and the data were analyzed with the numerical taxonomy multivariate analysis system (NTSYS-pc) software (Rohlf, 2000). Cluster analysis was done for the DNA bands with all primers using the unweighed pair group's method for arithmetic averages (UPGMA).

\section{Extraction and estimation of growth hormones}

The extraction was carried out according to Shindy and Smith (1975). Indole acetic acid (IAA), indole butyric acid (IBA) and abscisic acid (ABA) were estimated in the acidic ethyl acetate fraction after methylation according to Vogel (1975). Detection was carried out using an HPLC isocratic UV analyzer with an ODS Hyparsil $\mathrm{C}_{18}$ column (Müller and Hilgenberg, 1986). IAA, IBA and $A B A$ standards were used for quantifying corresponding hormone contents in tissues.

\section{RESULTS}

\section{Randomly amplified polymorphic DNA (RAPDs) analysis}

Polymerase chain reaction (PCR) amplification of random segments of genomic DNA was done using 10 primers of arbitrary nucleotide sequences. Table 2 shows the total number of bands generated by each primer for the isolates of the12 genotype under study, the number of polymorphic bands for each primer, and the \% of polymorphism. Study of the banding patterns showed that primers OPB-04 generated the most polymorphic bands $(93.3 \%)$, while the least polymorphic bands (10\%) were generated by the primer OPG-05. The DNA banding patterns, with the arbitrary used 10 primers, for the 12 Citrus cultivars under study are shown in Figure 1.

\section{Cluster analysis}

Cluster analysis for DNA variation showed splitting of the 12 studied Citrus accessions into two main sub-clusters (I and II):

Sub-cluster (I) comprised of four common sweet orange cultivars separated at 0.92 (the highest distance) which in turn were divided into two groups: Shamoty and Florida in one group while Fsido and Valencia in the other, where all were separated at lowest dissimilation distance (0.82).

Sub-cluster (II) comprised of sour and navel oranges that represent the Groups 3, 4, 5, 6 and 7 (Table 3). The two navel oranges El-Minya and El-Salheia were separated into two independent groups (4 and 6, respectively) whereas El-Qalubaiya and Wadi El-Mollak were linked together in Group 7.

\section{Endogenous indole auxins and abscisic acid contents}

Table 4 shows the result of IAA, IBA and auxin content of the 12 genotypes; the navel oranges had relatively high IAA and IBA contents, as compared with the other Citrus genotypes under investigation. Relatively lower auxin levels were recorded in the four genotypes of sour orange with a remarkably reduced content in the seeded cultivar. The common orange cultivars valencia, shamoty, fsido and florida exhibited variable contents, which were generally intermediate between those of navel and sour oranges. Abscisic acid (ABA) levels, on the other hand, were generally low in sour oranges and having inconsistently intermediate contents in the remaining genotypes except in those at El-Salheia and El-Minya. In these two accessions, the ABA levels were substantially higher than those of the plants grown at El-Qalubaiya and Wadi ElMollak. 
Table 2. The results of random amplified polymorphic DNA (RAPD) using 10 arbitrary primers.

\begin{tabular}{cccc}
\hline Primer & Total number of band & Number of polymorphic band & Polymorphic percent \\
\hline OPA-03 & 6 & 3 & 50 \\
OPA-07 & 6 & 2 & 33.3 \\
OPA-14 & 7 & 6 & 85.7 \\
OPA-19 & 10 & 7 & 70 \\
OPA-20 & 10 & 2 & 20 \\
OPB-04 & 15 & 14 & 93.3 \\
OPC-06 & 8 & 4 & 50 \\
OPG-05 & 5 & 1 & 10 \\
OPG-06 & 10 & 7 & 30 \\
OPG-07 & 7 & 3 & 42.85 \\
\hline
\end{tabular}

The table shows the used and the \% of polymorphism. The 12 DNA isolates are those of cultivars of four sour oranges (seedless, seeded, Brazilian, and Spanish), four sweet common oranges (Florida, Fsido, Shamoty, Valencia), and four sweet navel orange B21grown at four different localities in Egypt (El- Minya; South Egypt, ElQalubaiya governorate, El-Salheia; Sharqaia governorate, and Wadi El-Mollak;Ismailia governorate).

\section{DISCUSSION}

According to the report of Central Administration for Agricultural Extension Services, Ministry of Agriculture, Egypt (2003), the Citrus cultivated area in Egypt is 346000 feddans, producing about $38.2 \%$ of the national fruit yield. However, this yield (1809000 tons) is relatively low, as compared to the world levels. The private sector invested into establishment more than 10000 ha in the newly reclaimed desert areas outside the Nile valley, either as large-scale areas or small-scale farms. The main reasons for the relatively low productivity are inappropriate cultivation practices, old trees, lack of regular pruning, off-type cultivars, and poor irrigation practices, as well as graft-transmissible disease, which are known to endanger the Citrus industry worldwide (Hofer, 2007). Attempts have been devoted through the Citrus improvement program (CIP) in Egypt to establish a certification scheme according to international standards. One of the CIP programs (1999 to 2006) was assisted by GTZ (now GIZ) organization in cooperation with the Egyptian Ministry of Agriculture and Land Reclamation (MALR).

Propagation of orange trees implements grafting onto a root stock because high quality fruits cannot be maintained when trees are grown from seeds, cultivars are susceptible to root diseases, and grafted trees also begin bearing fruits many years earlier than trees reproduced by seeds (Bowman and Roman, 1999). Siraguse et al. (2006) stated that sour orange is the most widely used Citrus root stocks in the world. The sour orange (Citrus aurantium) is a hybrid between Citrus maxima and Citrus reticulata. The sour orange cultivars commonly used in Egypt are: seedless, sweet seeded, Brazilian and Spanish. The seedless populations of sour orange are genetically quite uniform because they arise from apomictic (parthenogenetic development of sex cells without fertilization) seed through nucellar embryony, where apomictically produced offsprings are genetically identical to the parent plant (Siraguse et al., 2006).

In the present study, the used samples represent accessions of four sour orange root stocks (seedless, sweet seeded, Brazilian and Spanish), four sweet orange cultivars (Florida, Fsido, Shamoty, and Valencia) and navel orange (B29) from four cultivation areas in Egypt having different climatic conditions. These four areas represented El-Minya; Upper Egypt, Wadi El-Mollac; Ismailia, El-Salheia (Sharquia governorate) and Qalubaiya, Northern Egypt. Navel orange planted in new desert areas at El-Minya and El-Salheia shows problems of reduced yield due to abscission of flowers and young fruits at earlier stages. Corresponding navel oranges at Wadi El-Mollac (desert area) and Qalubaiya are characterized by high yield.

The aforementioned variation concerning abscission was not clear to be genetic (arising from the original stocks) since the origin and date of parent root stocks introduction is uncertain or influenced physiologically by the climatic conditions. Thus, to clarify this point, random amplified polymorphic DNA (RAPD) technique has been used for DNA fingerprinting. This technique has been used as a precise strategy to identify Citrus species, cultivars, and biotypes and to investigate genetic diversity (Abkenar and Isshiki, 2003; Dehesdtani et al., 2007; Sahin-Çevik and Moore, 2012). Cluster analysis of DNA patterns showed that the 12 Citrus genotypes under investigation are linked at different similarity levels (Figure 2). The data showed separation of the four common local oranges at approximately similar distances, which indicated a relatively higher tightness of the cultivars Shamoty and Florida, on one hand and Fsido and Valencia, on the other hand. The four cultivars of sour orange were linked together with navel orange accessions in one cluster. But, separation of navel orange at 

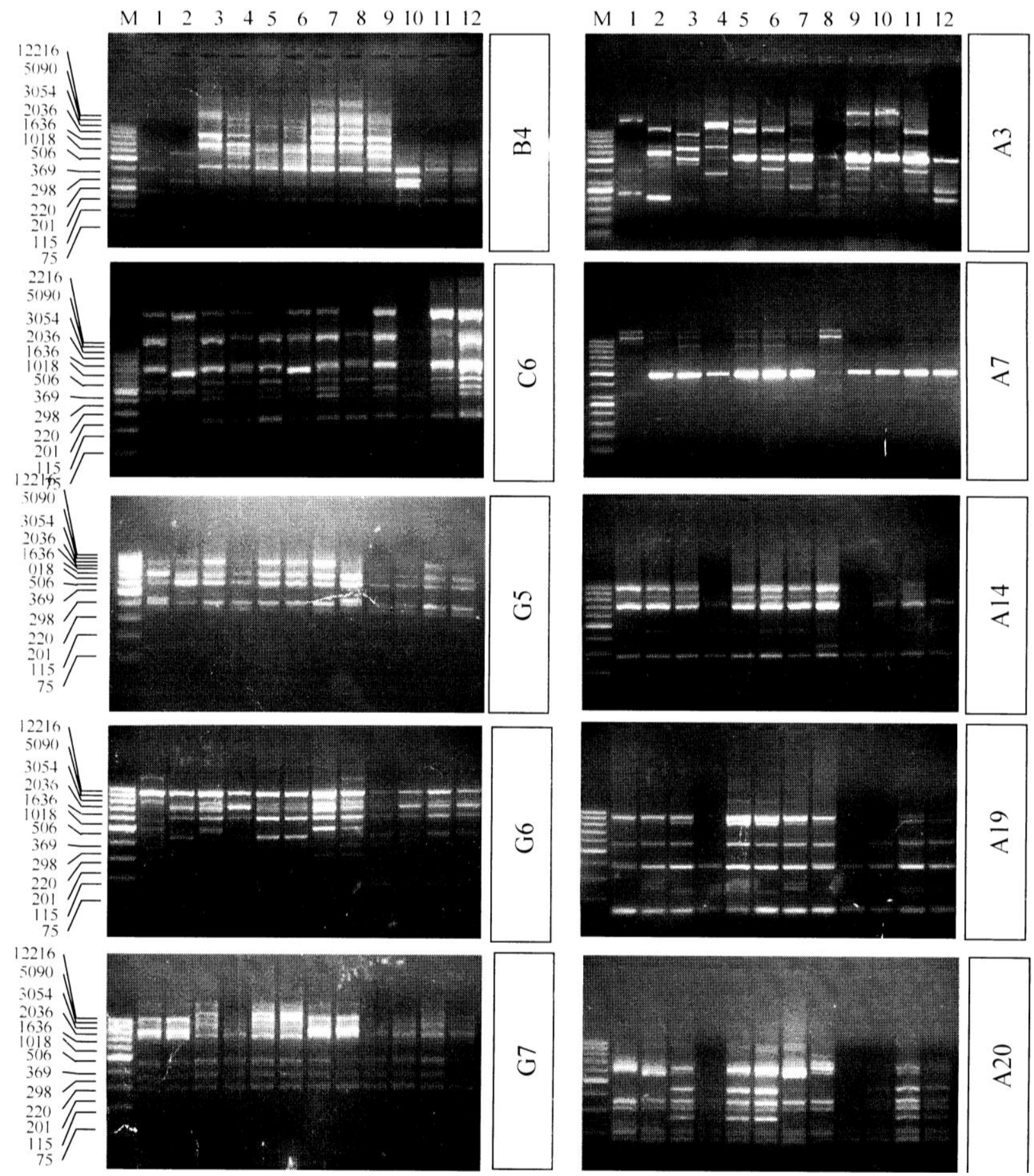

Figure 1. DNA banding pattern generated by the 10 primers for different genotypes of Citrus. The primers used were OPA-03, OPA-07, OPA-014, OPA-19, OPA-20 (A3, A7, A14, A19, A20, respectively), OPB-04, OPC-06, OPG-05, OPG06, OPG-07 (B4, C6, G5, G6, G7, respectively. M, weight marker; 1, 2, 3, 4 represent sour oranges (cvs. seedless, sweet seeded, Spanish, Brazilian, respectively); 5, 6, 7, 8 represent navel oranges from El- Minya, El-Qalubaiya, El-Salheia, and Wadi El-Mollak, respectively; 9,10,11,12 represent Fsido, Valencia, Shamoty and Florida respectively.

either El-Minya or El-Salheia, each into an independent group indicated polymorphic changes in DNA, compared to those grown at Wadi El-Mollac or Qalubaiya. The reasons for such diversification still need further work.
Plant growth and development are known to be regulated by hormones and environment, where both are genetically determined (Srivastava, 2002). Therefore, if navel orange at either El-Minya or El-Salheia are geneti- 
Table 3. The results of cluster analysis of 12 citrus cultivars based on RAPDs analysis using 10 arbitrary primers.

\begin{tabular}{|c|c|c|c|}
\hline Cluster & Group number & Accession number & Name \\
\hline \multirow{5}{*}{ I } & \multirow{2}{*}{1} & 11 & C. sinensis shamoty (common orange) \\
\hline & & 12 & C. sinensis florida (common orange) \\
\hline & & & \\
\hline & \multirow{2}{*}{2} & 9 & C. sinensis fsido (common orange) \\
\hline & & 10 & C. sinensis valencia (common orange) \\
\hline \multirow{8}{*}{ II } & \multirow{2}{*}{3} & 2 & C. aurantium seeded (sour orange) \\
\hline & & 1 & C. aurantium seedless (sour orange) \\
\hline & 4 & 8 & C. sinensis navel (EL-Minya) ${ }^{*}$ \\
\hline & \multirow{2}{*}{5} & 4 & C. aurantium Brazilian (sour orange) \\
\hline & & 3 & C. aurantium Spanish (sour orange) \\
\hline & 6 & 7 & C. sinensis navel (El-Salheia) * \\
\hline & \multirow{2}{*}{7} & 6 & C. sinensis navel (Wadi El-Mollak) \\
\hline & & 5 & C. sinensis navel (El-Qalubaiya) \\
\hline
\end{tabular}

*Navel orange showing flower and young fruit abscission.

Table 4. Indole acetic acid (IAA), indole butyric acid (IBA), and abscisic acid contents of the 12 Citrus genotypes under study. Phytohormone analysis was carried out in terminal buds following young leaves of branches.

\begin{tabular}{cllcc}
\hline Accession number & Scientific name & Common name & IAA + IBA $(\boldsymbol{\mu g} / \mathbf{1 0 0} \mathbf{g ~ D . W t})$ & $\mathbf{A B A}(\boldsymbol{\mu g} / \mathbf{1 0 0} \mathbf{~ D . W t})$ \\
\hline 1 & & Seedless & 2.34 & 0.4 \\
2 & Citrus aurantium & Seeded & 0.41 & 0.21 \\
3 & Sour orange & Spanish & 1.51 & 0.11 \\
4 & & Brazilian & 4.83 & 0.33 \\
5 & & El-Qalubaiya & 9.69 & 2.16 \\
6 & \multirow{4}{*}{ Citrus sinesis Navel } & Wadi-El-Mollak & 6.81 & 2.15 \\
7 & & El-Salheia* & 6.68 & 12.39 \\
8 & & El-Minya* & 8.87 & 11.90 \\
9 & & Fsido & 3.99 & 1.21 \\
10 & Citrus sinesis & Valencia & 6.75 & 2.40 \\
11 & Common orange & Shamoty & 6.39 & 2.73 \\
12 & & Florida & 1.84 & 0.60 \\
\hline
\end{tabular}

*Navel orange showing flower and young fruit abscission.

cally different from those at the other areas in Egypt (ElQalubaiya governorate and Wadi El-Mollak; Ismailia governorate), the plants would then be subjected to plasticity (open differentiation) and will show different hormonal and concomitant growth responses. In this connection, the two areas devoted to planting navel orange at El-Minya and El-Salheia are assumed to be rather subjected to drought effects than the remaining areas. Thus, the average year value of relative humidity is 34 and $37 \%$ at El-Minya and El-Salheia, respectively, compared to 53 and $50 \%$ at Ismailia (Wadi El-Mollac) and Qalubaiya, respectively. Average daily temperatures per year are $33,27,29$ and $30^{\circ} \mathrm{C}$ for El-Minya, Ismailia, Qalubaiya, and El-Salheia, respectively (World Climate
Data openweather.com (๑) 2011). Furthermore, both areas are subject of limited irrigation water and consequently, drip irrigation is applied, hence over irrigation is not expected. In this connection, over irrigation or drought has similar effects on flowering and early fruiting in Citrus. In the former case, the flower pedicle cannot afford the flow of excess water and under drought, the pedicle is subjected to dryness, so in both cases abscission would occur (Iglesias et al., 2007).

To clarify the scenario of drought prevalence at ElMinya and El-Salheia habitats, endogenous auxins and abscisic acid (ABA) levels were compared in the 12 Citrus genotypes under investigation. In general, auxin contents showed inconsistent results that could not be 


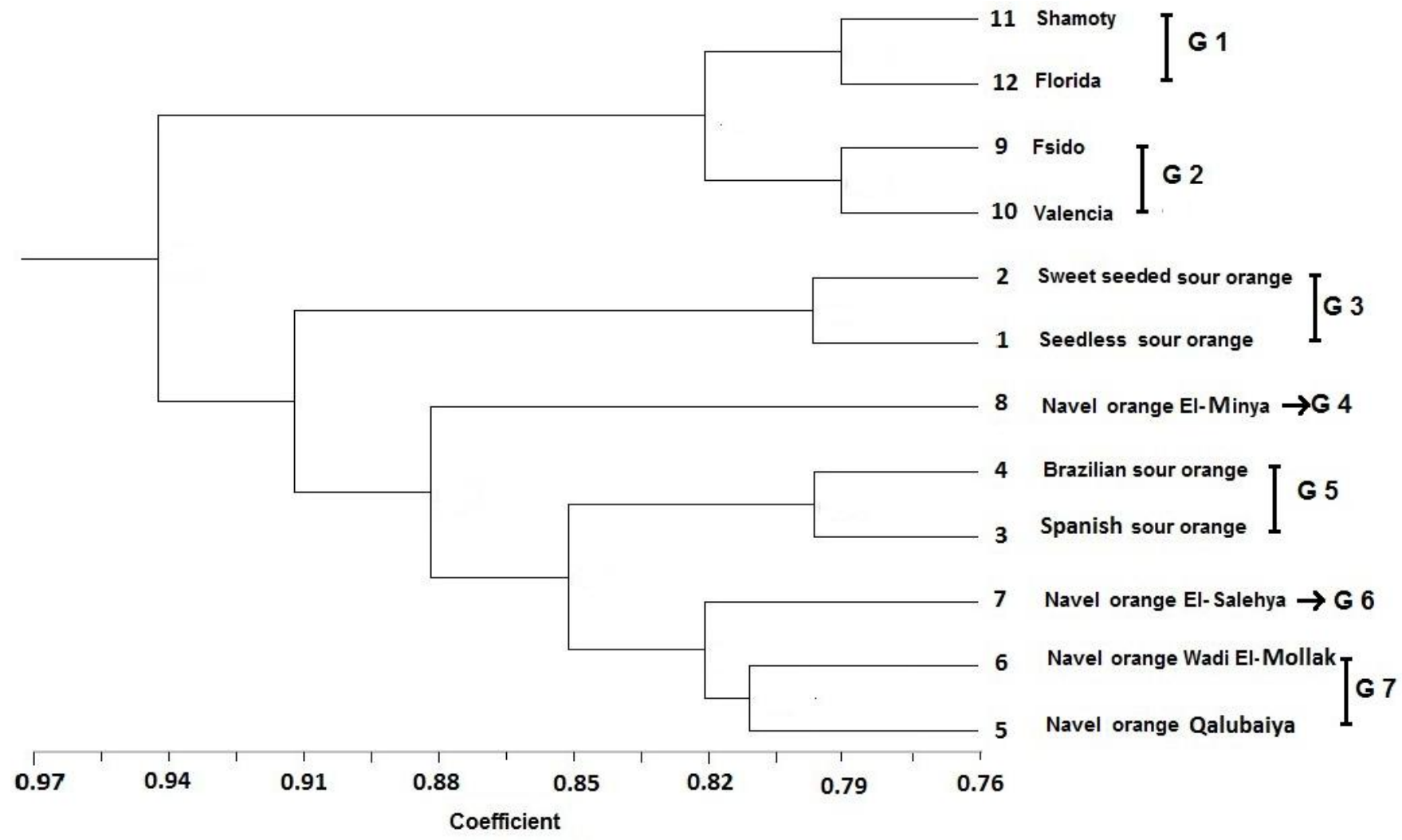

Figure 2. UPGMA dendrogram for cluster analysis of the RAPDs data of 12 accessions of Citrus. Scale bar shows genetic distance value. $G$ stands for group.

dependent on for comparison between the studied genotypes. But, ABA levels were substantially higher in navel orange at El-Minya and El-Salheia, compared to navel oranges at Wadi El-Mollac or Qalubaiya, on one hand, and to other genotypes of sour and common oranges, on the other hand. In this respect, the ratio of ABA content in either El-Salheia or El-Minya to that in Qalubaiya or Wadi El-Mollac showed over $550 \%$ increase. This result might verify water stress problems at El-Salheia or El-Minya since $A B A$ is an accurate marker in this respect (Bray et al., 2000). The major route to water deficit signals is ABA, where strong expression takes place for the gene 9-cisepoxycarotenoid dioxygenase; the key enzyme in ABA biosynthesis (Zeevaart, 1999; Wan and Li, 2006). ABA is transferred to the leaves through vascular tissues, decreasing stomatal conductance and modulating expression of various genes involved in adaptation to drying environment (Trejo et al., 1995).

Thus, it might be concluded that: (a) navel oranges (B29) are speculated to be not closely related in the four localities under investigation and assessment of these genotypes is important in order to accurately certify the Citrus products for global markets, (b) the variability between navel oranges in El-Salheia or El-Minya might be attributed to ambiguous origins and incorrect nomination of either the rootstocks or the scions during grafting, and (c) further research work is required to develop the performance of navel orange on root stocks other than sour orange, due to their drought tolerance and resistance to common diseases, such as Citrus jambhiri Lush (rough lemon), Citrus limonia Osbeck 'Volkamer' (volkameriana), Citrus sunki Tanaka (sour mandarin), etc. (citruspages/lemon, 2012).

\section{REFERENCES}

Abkenar AA, Isshiki S (2003). Molecular characterization and genetic diversity among Japanese acid citrus (Citrus spp.) based on RAPD markers. J. HortSci. Biotech. 78(1):108-112.

Ahmed HFS, Mahmoud AA, Hamid-Eldin NME, Bhieldin A (2005).

Gamma irradiation- and sodium azide induced changes in growth, leaf protein patterns and genomic DNA of two strains of maize under drought stress. Isotope Rad. Res. 37(1):1-17.

Agusti J, Zapater M, Iglesias DJ, Cercós M, Tadeo FR, Talon M (2007). Differential expression of putative 9cis-epoxycarotenoid dioxygenases and abscisic acid accumulation in water stressed vegetative and reproductive tissues of Citrus. Plant Sci. 172:85-94.

Bowman KD, Roman FM (1999). New rootstocks for orange and mandarin. Proc. Caribbean Food Crops Soc. 35:119-130.

Bray EA, Bailey-Serres J, Weretilnyk E (2000). Responses to abiotic stresses. In: W Gruissem, B Buchannan, R Jones (eds), Biochemistry and Molecular Biology of Plants. Amer. Soc. Plant Physiol., Rockville, MD. pp. 1158-1249.

Central Administration for Agricultural Extension Services Report, Ministry of Agriculture, Egypt (2003), CAAES 2003. Agricultural Extension Services, Ministry of Agriculture, Egypt. 
Chang-pin C, Liang-zhi, Ting L, Hai-tao T, Li C, Cai-lun J, Li-li L (2010). Effects of root stocks on fruit quality of jincheng orange. Acta Hort. Sinica .37(6):991-997.

CIP programs (1999-2006). Assisted by GTZ (now GIZ) organization in cooperation with the Egyptian Ministry of Agriculture and Land Reclamation (MALR).

Citruspages/lemons 2012. users.kymp.net/citruspages/lemons.html.

Dehesdtani A, Kazemitabar SK, Rahimiam H (2007). Assessment of genetic diversity of navel sweet orange cultivars grown in Mazandaran Province using RAPD markers. Asian J. Plant Sci. 6(7):1119-1124.

Dellaporta SL, Wood J, Hicks JB (1983). A plant DNA mini preparation: version II. Plant Mol. Biol. Rep. 1:19-21.

FAO (2006). Fresh and processed Citrus fruit annual statistics. Commodities and Trade Division, Food and Agriculture Organization of the United Nations, Rome, Italy.

Golein B, Nazeryan M, Babakhani B (2012). Assessing genetic variability in male sterile and low fertile Citrus cultivars utilizing simple sequence repeat markers (SSRs). Afr. J. Biotech. 11(7):1632-1638.

Gómez-Cadenas A, Tadeo FR, Talon M, Primo-Millo E (1996). Leaf abscission induced by ethylene in water stressed intact seedlings of (Citrus reshni Hort. ex Tan.) requires previous abscisic acid accumulation in roots. Plant Physiol. 112:401-408.

Goren R (1993). Anatomical, physiological and hormonal aspects of abscission in Citrus. Hort. Rev. 15:33-46.

Guardiola JL, Monerri C, Agusti M (1982). The inhibitory effect of gibberellic acid on flowering in Citrus. Physiol. Plant. 55:136-142.

Hofer J (2007). Achievements and impact of the Citrus improvement program (CIP) in Egypt.

Iglesias DJ, Cercos M, Colmenero-Flores JM, Naranjo MA, Rios G, Carrera E, Ruiz-Rivero O, Lliso I, Morillon R, Tadeo FR, Talon M (2007). Physiology of Citrus fruiting. Braz. J. Plant Physiol. 19(4):331362.

Kimball DA (1999). Citrus Processing: a complete guide (2d ed.). New York: Springer. p. 450.

Lliso I, Forner JB, Talon M (2004). The dwarfing mechanism of the Citrus rootstocks F\&A 418 and \#23 is related to the competition between vegetative and reproductive development. Tree Physiol. 24:225-232.

Mehouachi J, Gómez-Cadenas A, Primo-Millo E, Talon M (2005). Antagonistic changes between abscisic acid and gibberellins in Citrus fruits subjected to a series of different water conditions. J. Plant Growth Regul. 24:179-187.

Muller P, Hilgenberg W (1986). Isomers of Zeatin and Zeatin riboside in club root tissue: evidence for transzeatin biosynthesis by Plasmodiophora brassica. Physiol. Plant 66:245-250.

Ollitrault F, Terol J, Pina JA, Navarro L, Talon M, Ollitrault P (2010). Development of SSR markers from Citrus clementine (Rutaceae) BAC end sequences and interspecific transfer-ability in Citrus. Am. J. Bot. 97(11):124-129.

Rohlf FJ (2000). NTSYS-pc: Numerical Taxonomy and Multivariate Analysis System.Version 2.1. Exceter Software, New York, USA.
Şahin-Çevik M, Moore GA (2012). Quantitative trait loci analysis of morphological traits in Citrus. Plant Biotech. Rep. 6(1):47-57.

Shindy WW, Smith O (1975). Identification of plant hormones from cotton ovules. Plant Physiol. 55:550-554.

Siraguse M, Pasquale F, Abbate L, Tusa N (2006). Identification of sour orange accessions and evaluation of their genetic variability by molecular marker analysis. Hort. Sci. 41(1):84-89.

Snoussi H, Duval MF, Garcia-Lor A, Belfalah Z, Froelicher Y, Risterucci AM, Perrier X, Jacquemoud-Collet JP, Navarro L, Harrabi M, Ollitrault $P$ (2012). Assessment of the genetic diversity of the Tunisian citrus rootstock germplasm. BMC Genet. 13:16.

Srivastava LM (2002). Abscisic and stress tolerance in plants. In: Plant Growth and Development. Academic Press, New York. pp. 381- 427.

Talon M, Gmitter Jr FG (2008). Citrus Genom. Int. J. Plant Genom. 2008:528361.

Tanaka T (1977). Fundamental discussion of Citrus classification. Studia Citrolog. Osaka 14:1-6.

Tang N, Zhang H, Li X, J Xiao, Xiong L (2012). Constitutive activation of transcription factor OsbZIP46 Improves drought tolerance in rice. Plant Physiol. 158(4):1755-1768.

Trejo CL, Clephan AL, Davies WJ (1995). How do stomata read abscisic acid signals? Plant Physiol. 109:808-811.

Vogel AJ (1975). A Test Book of Practical Organic Chemistry $3^{\text {rd }}$ ed., English Language Book Society and Longmans Growth Ltd.

Wan XR, Li L (2006). Regulation of ABA level and water stress tolerance of Arabidopsis by ectopic expression of a peanut 9-cisepoxycarotenoid dioxygenase gene. Bichem. Biophy. Res. Commun. 347(4):1030-1038.

World Climate Data openweather.com@

Wutscher HK, Bowman KD (1999). Performance of 'valencia' orange on 21 root stocks. Hort. Sci. 34:622-624.

Zeevaart JAD (1999). Abscisic acid metabolism and its regulation. In: Biochemistry and Molecular Biology of Plant Hormones, Hall, M. and K. Libbenga (Eds.). Elsevier Science BV, Amsterdam. pp.189-207. 